\title{
Genetic structure and
}

phylogeography of alpine relict populations of Ranunculus

pygmaeus and Saxifraga cernua

\section{Journal Article}

Author(s):

Bauert, Martin R.; Kälin, Martin; Edwards, Peter J.; Baltisberger, Matthias

Publication date:

2007

Permanent link:

https://doi.org/10.3929/ethz-b-000006503

Rights / license:

In Copyright - Non-Commercial Use Permitted

Originally published in:

Botanica Helvetica 117(2), https://doi.org/10.1007/s00035-007-0826-7 


\title{
Genetic structure and phylogeography of alpine relict populations of Ranunculus pygmaeus and Saxifraga cernua
}

\author{
Martin R. Bauert ${ }^{1}$, Martin Kälin, Peter J. Edwards and Matthias Baltisberger \\ Institute of Integrative Biology, ETH Zürich, Universitätstrasse 16, CH-8092 Zürich; \\ e-mail: matthias.baltisberger@env.ethz.ch \\ ${ }^{1}$ present address: Zoo Zürich, Zürichbergstrasse 221, CH-8044 Zürich
}

Manuscript accepted 25 October 2007

\begin{abstract}
Bauert M. R., Kälin M., Edwards P. J. and Baltisberger M. 2007. Genetic structure and phylogeography of alpine relict populations of Ranunculus pygmaeus and Saxifraga cernua. Bot. Helv. 117: 181-196.

Ranunculus pygmaeus and Saxifraga cernua are arctic-alpine species with similar disjunct distributions: both occur as small, isolated relict populations in the Alps, while they are more widespread in the Arctic. To improve our understanding of their glacial and postglacial history, we investigated their genetic diversity within and among populations collected in the Alps and in the Arctic using 80 RAPD primers. We found only two genotypes of $R$. pygmaeus, one in the Alps and one in the Arctic. The absence of genetic diversity within each region is probably the consequence of postglacial colonization from a single source, followed by inbreeding in very small populations. In $S$. cernua, we found six genotypes among 11 populations in the Alps but no genetic variation within alpine populations. This limited genetic variation probably results from an extreme reduction and fragmentation of populations during successive glacial periods. In contrast, there was a high level of genetic variation both among and within all arctic populations of $S$. cernua. We suggest that this arose at least partly through the immigration of plants from multiple sources after the last glaciation. The higher genetic diversity of $S$. cernua compared to $R$. pygmaeus might also be related to their contrasting breeding systems: $R$. pygmaeus is an inbreeding diploid which propagates only by seeds, while $S$. cernua is a clonal polyploid which propagates mainly by vegetative means. Clonal growth, by prolonging the life span of a genotype, might contribute to the maintenance of genetic diversity under conditions which are difficult for sexual reproduction and seedling establishment.
\end{abstract}


Key words: Arctic-alpine species, chromosome numbers, genetic diversity, nunataks, post-glacial colonization, RAPD, tabula rasa.

\section{Introduction}

Genetic diversity within a plant population is influenced by many factors including breeding system, life form, and the size and history of the population (Hamrick and Godt 1996). Populations of widely distributed, outbreeding species of seed plants often contain high genetic diversity (Hamrick and Godt 1989), but this is usually not the case for clonal or inbreeding species (Ellstrand and Roose 1987; Bauert 1996). An adequate level of diversity is thought to be important for the long-term survival of a population because it permits genetic adaptation to changing environmental conditions (Lande and Shannon 1996). However, population bottlenecks, founder events and genetic drift can lead to unpredictable fluctuations in allelic frequencies in small populations (Ellstrand and Elam 1993; Knapp and Connors 1999), which therefore tend to be less genetically diverse than large populations. As a result, plant species that underwent large-scale migrations during or after the Pleistocene glaciations tend to have lower levels of genetic diversity than related taxa still growing in their putative Pleistocene refugia (Mosseler et al. 1993; Lewis and Crawford 1995).

Many arctic-alpine species have been affected by glacial and postglacial bottlenecks (Schönswetter et al. 2006; Alsos et al. 2007). These include Ranunculus pygmaeus and Saxifraga cernua, two perennial forbs with similar arctic-alpine, disjunct distributions. In the Alps both species occur in small relict populations that have probably been isolated since the last Pleistocene glaciation (Gams 1933), although opinions differ on how they reached their present locations. Melchior (1934) suggested that the species colonized the Alps during interglacial periods of the Pleistocene glaciation and survived at least the last glaciation on mountain ranges not covered by ice. This nunatak hypothesis seems plausible, since numerous mountain peaks in the Alps are known to have protruded through the ice sheet (Jäckli 1965), while some ranges, especially in the south-eastern part of the Alps were never covered by ice. This south-eastern region is especially rich in endemic and taxonomically isolated species, many of which are probably Tertiary relicts (Ozenda 1988; Burga and Perret 1998; Stehlik 1999). Furthermore, recent molecular genetic studies (Holderegger et al. 2002; Stehlik 2003; Schönswetter et al. 2005; Bettin et al. 2007) have provided convincing evidence that several alpine species (including Eritrichium nanum, Rumex nivalis, Saxifraga oppositifolia and Senecio halleri) did survive in situ. In the case of S. cernua, however, the nunatak hypothesis is contradicted by the fact that all known alpine populations grow in places that were covered by ice, at least during the most extensive Riss glaciation. For this reason, La Nicca (1945) and Hantke (1983) concluded that S. cernua (and probably also $R$. pygmaeus) immigrated after the last glaciation from refugia outside the Alps.

The European Arctic was even more affected than the Alps by the Pleistocene glaciation, with a continuous ice sheet covering Scandinavia and extending into central Europe. There has been a similar discussion as for the Alps concerning the Quaternary history of the arctic flora, with two main hypotheses being proposed (Dahl 1987, 1997; Tollefsrud et al. 1998). According to the 'nunatak' or 'glacial refuge' hypothesis many species survived the last glaciation upon nunataks or coastal refugia in Scandinavia (Berg 1963; Dahl 1987). In contrast, the tabula rasa hypothesis postulates that the entire 
Scandinavian flora survived in areas outside the ice sheet, but that species were able to migrate and colonize rapidly under the conditions prevailing after the end of the last ice age (Birks 1993; Brochmann et al. 1996). Recent studies of several arctic species have revealed only weak genetic differentiation among widely separated populations, with no hot spots of genetic diversity in Scandinavia that might represent areas where plants survived the Pleistocene glaciation (Brochmann et al. 1996; Gabrielsen et al. 1997; Nordal and Jonsell 1998; Tollefsrud et al. 1998). These findings have led Brochmann et al. (2003) to conclude that present-day patterns of endemism and disjunction in the North Atlantic region can be explained without invoking in situ glacial survival.

To improve our understanding of the glacial and postglacial history of $R$. pygmaeus and $S$. cernua, we investigated their genetic diversity in a broad range of alpine and arctic populations, with numerous individuals per population. We specifically addressed the following questions:

(i.) What level of genetic diversity is present in relict alpine populations?

(ii.) Does genetic diversity differ between relict alpine populations and populations of the continuous distribution area in Scandinavia?

(iii.) Is there a regional pattern in genetic variation among populations, and is it consistent with the nunatak or the tabula rasa hypothesis?

\section{Materials and Methods}

\section{Plant material}

Ranunculus pygmaeus has a circumpolar distribution and occurs throughout the European and North American Arctic, in Siberia and in Greenland. In the Alps only 27 relict populations are known, most of them in Austria. $R$. pygmaeus is a diploid $(2 \mathrm{n}=$ 16) perennial that reproduces only by seeds. It produces no runners or other structures allowing vegetative propagation.

Saxifraga cernua has a circumpolar distribution in Siberia, Greenland, the North American and European Arctic, and scattered populations also occur in the Alps, Scotland and the Carpathian Mountains. About 30 populations of $S$. cernua have been recorded in the Alps (Gams 1933; Melchior 1934). It is a polyploid perennial that propagates clonally by means of bulbils produced in the inflorescence below the terminal flower.

Plant material was sampled in three alpine regions and two arctic regions (Svalbard and northern Sweden) with 2-6 populations per region (Tab. 1). For S. cernua, two populations were additionally sampled in the Ural, a region which was less affected by the last glaciation. $R$. pygmaeus was not sampled in the Ural, and in the Alps, it occurs only in the central-eastern part, so only three regions were sampled for this species (Tab. 1). From each population, we sampled 6 to 25 plants whenever possible (Tab. 1). In the genetically almost unvariable $R$. pygmaeus (see below), we investigated 24-25 individuals in one population per region and just one to six randomly selected individuals from the other populations. In the genetically variable $S$. cernua, all sampled individuals were investigated. 
Tab. 1. Collection information and genetic diversity of Saxifraga cernua and Ranunculus pygmaeus populations: site description with altitude and coordinates; population size (approximate number of flowering individuals); $\mathrm{N}$ (number of individuals analyzed for RAPD variation); number of genotypes detected; Simpson diversity index (Ds) for regions and for populations; chromosome numbers $(2 \mathrm{n})$.

Population and site

Population
size $\quad \mathrm{N} \begin{gathered}\text { Geno- } \\ \text { types }\end{gathered}$ Ds $2 \mathrm{n}$

\section{Saxifraga cernua}

\begin{tabular}{|c|c|c|c|c|c|}
\hline \multicolumn{3}{|c|}{ Arctic: Svalbard } & \multirow{2}{*}{$\begin{array}{l}30 \\
11\end{array}$} & \multirow{2}{*}{$\frac{20}{5}$} & \multirow{2}{*}{$\frac{0.96}{0.78}$} \\
\hline S1 & $\begin{array}{l}\text { Endalen: along brook, wet, } 50 \mathrm{~m} \text { a.s.l., } 78^{\circ} 11^{\prime} \mathrm{N} \text {, } \\
15^{\circ} 45^{\prime} \mathrm{E}\end{array}$ & 500 & & & \\
\hline S2 & $\begin{array}{l}\text { Foxdalen: arctic tundra, moist, } 50 \mathrm{~m} \text { a.s.l., } 78^{\circ} 10^{\prime} \mathrm{N} \text {, } \\
16^{\circ} 13^{\prime} \mathrm{E}\end{array}$ & $1000-2000$ & 9 & 6 & 0.90 \\
\hline S3 & $\begin{array}{l}\text { Pyramiden: fellfield, moist depression, } 70 \text { m a.s.l., } \\
78^{\circ} 39^{\prime} \mathrm{N}, 16^{\circ} 19^{\prime} \mathrm{E}\end{array}$ & 100 & 10 & 9 & 0.97 \\
\hline \multicolumn{3}{|c|}{ Arctic: Scandinavia (northern Sweden) } & 42 & 23 & 0.93 \\
\hline S4 & $\begin{array}{l}\text { Slåttatjåkka: moist alpine tundra, } 1060 \mathrm{~m} \text { a.s.l., } \\
68^{\circ} 21^{\prime} \mathrm{N}, 18^{\circ} 40^{\prime} \mathrm{E}\end{array}$ & 200 & 9 & 4 & 0.69 \\
\hline S5 & $\begin{array}{l}\text { Latnjajávri: along small brook, wet soil, } 1000 \mathrm{~m} \\
\text { a.s.l., } 68^{\circ} 22^{\prime} \mathrm{N}, 18^{\circ} 30^{\prime} \mathrm{E}\end{array}$ & 200 & 11 & 5 & 0.71 \\
\hline S6 & Kärkevagge: snowbed, $760 \mathrm{~m}$ a.s.1., $68^{\circ} 23^{\prime} \mathrm{N}, 18^{\circ} 21^{\prime} \mathrm{E}$ & 300 & 11 & 10 & 0.98 \\
\hline S7 & $\begin{array}{l}\text { Fløya Mountain: north exposed limestone, } 460 \mathrm{~m} \\
\text { a.s.l., } 69^{\circ} 00^{\prime} \mathrm{N}, 19^{\circ} 00^{\prime} \mathrm{E}\end{array}$ & 200 & 11 & 4 & 0.49 \\
\hline \multicolumn{2}{|l|}{ Ural } & & 11 & 6 & 0.71 \\
\hline S9 & $\begin{array}{l}\text { Kosvinski Kamen: mountain tundra, } 1000 \text { m a.s.l., } \\
59^{\circ} 30^{\prime} \mathrm{N}, 59^{\circ} 08^{\prime} \mathrm{E}\end{array}$ & 1000 & 10 & 5 & 0.64 \\
\hline S10 & $\begin{array}{l}\text { Severnaya Sosva River: below lime rocks along } \\
\text { river, } 90 \mathrm{~m} \text { a.s.l., } 60^{\circ} 14^{\prime} \mathrm{N}, 60^{\circ} 23^{\prime} \mathrm{E}\end{array}$ & 10 & 1 & 1 & - \\
\hline
\end{tabular}

\begin{tabular}{|c|c|c|c|c|c|c|}
\hline West & ern Alps & & 40 & 2 & 0.49 & \\
\hline S11 & $\begin{array}{l}\text { Italy, Passo delle Capre: north exposed, moist, } \\
2480 \mathrm{~m} \text { a.s.l., } 44^{\circ} 10^{\prime} \mathrm{N}, 7^{\circ} 41^{\prime} \mathrm{E}\end{array}$ & 50 & 17 & 1 & 0 & \\
\hline S12 & $\begin{array}{l}\text { Switzerland, Diablerets: north exposed below big } \\
\text { rock, } 2385 \mathrm{~m} \text { a.s.l, } 46^{\circ} 21^{\prime} \mathrm{N}, 7^{\circ} 13^{\prime} \mathrm{E}\end{array}$ & 60 & 7 & 1 & 0 & \\
\hline S13 & $\begin{array}{l}\text { Switzerland, Cry d'Er: north exposed grottos, } \\
2190 \text { m a.s.l, } 46^{\circ} 20^{\prime} \mathrm{N}, 7^{\circ} 28^{\prime} \mathrm{E}\end{array}$ & 150 & 7 & 1 & 0 & 52 \\
\hline S14 & $\begin{array}{l}\text { Switzerland, Les Outannes: north exposed grottos, } \\
2350 \mathrm{~m} \text { a.s.l, } 46^{\circ} 22^{\prime} \mathrm{N}, 7^{\circ} 33^{\prime} \mathrm{E}\end{array}$ & 100 & 9 & 1 & 0 & \\
\hline
\end{tabular}

\begin{tabular}{|c|c|c|c|c|c|c|}
\hline Cent & al-eastern Alps & & 53 & 2 & 0.20 & \\
\hline $\mathrm{S} 15$ & $\begin{array}{l}\text { Switzerland, Piz Arina: mountain peak, } 2828 \mathrm{~m} \text { a.s.l, } \\
46^{\circ} 52^{\prime} \mathrm{N}, 10^{\circ} 23^{\prime} \mathrm{E}\end{array}$ & $3000-5000$ & 12 & 1 & 0 & $60^{*}$ \\
\hline S16 & $\begin{array}{l}\text { Switzerland, Piz Alpetta: ridge, moist limestone, } \\
2750 \text { m a.s.l., } 46^{\circ} 56^{\prime} \mathrm{N}, 10^{\circ} 27^{\prime} \mathrm{E}\end{array}$ & $1000-3000$ & 23 & 1 & 0 & \\
\hline S17 & $\begin{array}{l}\text { Austria, Schmalzkopf: on the very top, } 2720 \mathrm{~m} \text { a.s.l, } \\
46^{\circ} 56^{\prime} \mathrm{N}, 10^{\circ} 28^{\prime} \mathrm{E}\end{array}$ & $200-500$ & 12 & 1 & 0 & 60 \\
\hline S18 & $\begin{array}{l}\text { Austria, Sinabel: moist limestone, } 2349 \mathrm{~m} \text { a.s.l., } \\
47^{\circ} 27^{\prime} \mathrm{N}, 13^{\circ} 41^{\prime} \mathrm{E}\end{array}$ & 6 & 6 & 1 & 0 & \\
\hline
\end{tabular}


Tab. 1. (continued)

\begin{tabular}{|c|c|c|c|c|c|c|}
\hline \multicolumn{2}{|c|}{ Population and site } & $\begin{array}{l}\text { Population } \\
\text { size }\end{array}$ & $\mathrm{N}$ & $\begin{array}{l}\text { Geno- } \\
\text { types }\end{array}$ & Ds & $2 n$ \\
\hline \multicolumn{2}{|c|}{ South-eastern Alps } & & 37 & 2 & 0.47 & \\
\hline S19 & $\begin{array}{l}\text { Austria, Hochtristen: north exposed, moist, } 2536 \mathrm{~m} \\
\text { a.s.l., } 46^{\circ} 48^{\prime} \mathrm{N}, 13^{\circ} 08^{\prime} \mathrm{E}\end{array}$ & 20 & 13 & 1 & 0 & \\
\hline S20 & $\begin{array}{l}\text { Italy, Sella Joch: north-west side below big rock, } \\
2360 \mathrm{~m} \text { a.s.l, } 46^{\circ} 31^{\prime} \mathrm{N}, 11^{\circ} 46^{\prime} \mathrm{E}\end{array}$ & $500-1000$ & 12 & 1 & 0 & $\begin{array}{l}42 \\
45\end{array}$ \\
\hline $\mathrm{S} 21$ & $\begin{array}{l}\text { Italy, Porta Vescova: north side, between big rocks, } \\
2350 \mathrm{~m} \text { a.s.l, } 46^{\circ} 28^{\prime} \mathrm{N}, 11^{\circ} 53^{\prime} \mathrm{E}\end{array}$ & $100-200$ & 12 & 1 & 0 & $\begin{array}{l}46 \\
47\end{array}$ \\
\hline
\end{tabular}

\section{Ranunculus pygmaeus}

\begin{tabular}{|c|c|c|c|c|c|}
\hline \multicolumn{3}{|c|}{ Arctic: Svalbard } & \multirow{2}{*}{$\begin{array}{l}8 \\
1\end{array}$} & \multirow{2}{*}{$\begin{array}{l}1 \\
1\end{array}$} & \multirow[t]{2}{*}{0} \\
\hline $\mathrm{R} 1$ & Endalen: wet riverside, $50 \mathrm{~m}$ a.s.l., $78^{\circ} 11^{\prime} \mathrm{N}, 15^{\circ} 45^{\prime} \mathrm{E}$ & 1000 & & & \\
\hline $\mathrm{R} 2$ & $\begin{array}{l}\text { Bolterdalen: below snow accumulation, } 50 \mathrm{~m} \text { a.s.l., } \\
78^{\circ} 10^{\prime} \mathrm{N}, 16^{\circ} 00^{\prime} \mathrm{E}\end{array}$ & $>5000$ & 1 & 1 & - \\
\hline R3 & Foxdalen: old riverbed, $50 \mathrm{~m}$ a.s.l., $78^{\circ} 10^{\prime} \mathrm{N}, 16^{\circ} 13^{\prime} \mathrm{E}$ & $>5000$ & 1 & 1 & - \\
\hline $\mathrm{R} 4$ & Todalen: snowbed, $100 \mathrm{~m}$ a.s.l., $78^{\circ} 09^{\prime} \mathrm{N}, 15^{\circ} 50^{\prime} \mathrm{E}$ & 1000 & 5 & 1 & 0 \\
\hline \multicolumn{3}{|c|}{ Arctic: Scandinavia (northern Sweden) } & 31 & 1 & 0 \\
\hline R5 & $\begin{array}{l}\text { Slåttatjåkka: snowbed, } 1060 \mathrm{~m} \text { a.s.l., } 68^{\circ} 21^{\prime} \mathrm{N} \text {, } \\
18^{\circ} 40^{\prime} \mathrm{E}\end{array}$ & 500 & 1 & 1 & - \\
\hline R6 & Latnjavaggi: fellfield, $1060 \mathrm{~m}$ a.s.l., $68^{\circ} 22^{\prime} \mathrm{N}, 18^{\circ} 30^{\prime} \mathrm{E}$ & 500 & 1 & 1 & - \\
\hline $\mathrm{R} 7$ & Latnja: springswamp, $980 \mathrm{~m}$ a.s.l., $68^{\circ} 21^{\prime} \mathrm{N}, 18^{\circ} 30^{\prime} \mathrm{E}$ & 200 & 1 & 1 & - \\
\hline $\mathrm{R} 8$ & $\begin{array}{l}\text { Latnjacorru: snowbed, } 1310 \mathrm{~m} \text { a.s.1., } 68^{\circ} 23^{\prime} \mathrm{N} \text {, } \\
18^{\circ} 30^{\prime} \mathrm{E}\end{array}$ & 5000 & 25 & 1 & 0 \\
\hline R9 & $\begin{array}{l}\text { Fløya Mountain: snowbed, } 50 \mathrm{~m} \text { a.s.l, } 69^{\circ} 00^{\prime} \mathrm{N}, \\
19^{\circ} 00^{\prime} \mathrm{E}\end{array}$ & 50 & 3 & 1 & 0 \\
\hline \multicolumn{3}{|c|}{ Central-eastern Alps } & 54 & 1 & 0 \\
\hline $\mathrm{R} 10$ & $\begin{array}{l}\text { Switzerland, Macun: snowbed, } 2640 \mathrm{~m} \text { a.s.l., } \\
46^{\circ} 44^{\prime} \mathrm{N}, 10^{\circ} 08^{\prime} \mathrm{E}\end{array}$ & 70 & 6 & 1 & 0 \\
\hline R11 & $\begin{array}{l}\text { Austria, Horntaler Joch: snowbed, } 2650 \mathrm{~m} \text { a.s.l., } \\
47^{\circ} 06^{\prime} \mathrm{N}, 11^{\circ} 10^{\prime} \mathrm{E}\end{array}$ & 1000 & 24 & 1 & 0 \\
\hline $\mathrm{R} 12$ & $\begin{array}{l}\text { Austria, Geistbeckweg: snowbed, } 2560 \mathrm{~m} \text { a.s.l., } \\
47^{\circ} 00^{\prime} \mathrm{N}, 11^{\circ} 35^{\prime} \mathrm{E}\end{array}$ & 500 & 6 & 1 & 0 \\
\hline $\mathrm{R} 13$ & $\begin{array}{l}\text { Austria, St. Pöltner Hütte: snowbed, } 2500 \text { m a.s.l., } \\
47^{\circ} 10^{\prime} \mathrm{N}, 12^{\circ} 30^{\prime} \mathrm{E}\end{array}$ & 250 & 6 & 1 & 0 \\
\hline R14 & $\begin{array}{l}\text { Austria, Zirmsee: snowbed, } 2530 \mathrm{~m} \text { a.s.l., } 47^{\circ} 04^{\prime} \mathrm{N} \text {, } \\
12^{\circ} 56^{\prime} \mathrm{E}\end{array}$ & 250 & 6 & 1 & 0 \\
\hline $\mathrm{R} 15$ & $\begin{array}{l}\text { Austria, Weisssee: snowbed, } 2420 \mathrm{~m} \text { a.s.l., } 47^{\circ} 01^{\prime} \mathrm{N} \text {, } \\
13^{\circ} 01^{\prime} \mathrm{E}\end{array}$ & 500 & 6 & 1 & 0 \\
\hline
\end{tabular}

* from Küpfer and Rais (1983) 


\section{Genetic analyses}

We used the RAPD method (Random Amplified Polymorphic DNA) to investigate genetic variation within and among arctic and alpine populations of $R$. pygmaeus and $S$. сегnиa. This method has proved useful in similar studies of genetic variation in many plant species (Bachmann 1994), and has the advantage of requiring very little plant material. The fact that we could extract sufficient DNA for our analyses from a single leaf was an important consideration because both study species are legally protected in the Alps. The method has been criticised because the expression of RAPD bands can be sensitive to slight changes in reaction conditions, leading to low reproducibility. However, Kjolner et al. (2004) showed that conclusions about clonal diversity in $S$. cernua reached using RAPDs were almost identical to those obtained using AFLPs (Amplified Fragment Length Polymorphisms), and concluded that if carefully used the RAPD method produces reliable results and is appropriate for such studies. In our case, RAPD data reported previously for seven alpine populations of $S$. cernua (Bauert et al. 1998) were included in the new data set. To check the reproducibility of our results, we repeated the analysis of six plants from the earlier study on each PCR plate. The PCR-amplification for all arctic S. cernua samples was done twice and run side by side on the same gel.

Two or three basal leaves were collected per plant and dried in small glass tubes with a surplus of silica gel. The total DNA of single leaves was extracted according to the procedure of Doyle and Doyle (1991). Dry leaves were ground in a mill and incubated for 30 minutes at $65^{\circ}$ in a CTAB isolation buffer $(1 \%$ CTAB, $0.7 \mathrm{M} \mathrm{NaCl}, 10 \mathrm{mM}$ EDTA, 2\% PVP, and 5\% mercaptoethanol in $100 \mathrm{mM}$ Tris- $\mathrm{HCl}$ at $\mathrm{pH} 8$ ). DNA was extracted twice with chloroform-isoamyl alcohol (24:1); it was then precipitated with cold isopropanol, washed with $70 \%$ and $100 \%$ ethanol, and air dried at room temperature. The resulting pellet was resuspended in $0.1 \mathrm{M}$ TE with $10 \mathrm{mg} / \mathrm{ml} \mathrm{RNAse.}$ DNA-concentration was determined on a Hoefer TKO 100 fluorometer.

Polymerase chain reaction (PCR) with arbitrary primers for obtaining random amplified polymorphic DNA (RAPD) was performed according to the method of Williams et al. (1990). We used $5 \mathrm{ng}$ DNA template, $0.3 \mu \mathrm{M}$ primer (Operon Technologies, Alameda, California), 1 U SuperTaq polymerase, $2.5 \mu \mathrm{l} \mathrm{PCR}$ buffer (both from HT Biotechnology, Cambridge, England), and $100 \mu \mathrm{M}$ of each dNTP for each $25 \mu \mathrm{l}$ PCR reaction, respectively. Amplification was performed in a MJ Research Inc. PTC100 thermal cycler programmed for an initial $120 \mathrm{sec}$ at $94^{\circ}$, followed by 40 cycles of $20 \mathrm{sec}$ at $94^{\circ}, 30 \mathrm{sec}$ at $40^{\circ}$, and $90 \mathrm{sec}$ at $72^{\circ}$, and ending with $5 \mathrm{~min}$ at $72^{\circ}$. Amplification products were analyzed by electrophoresis on $1.25 \%$ agarose gels and visualized by staining with ethidium bromide.

To select polymorphic primers for $R$. pygmaeus we screened 80 decamer primers (Operon A1-20, B1-20, C1-20, D1-20) with one scandinavian and one alpine individual. We selected those 21 primers producing clear banding patterns for a screen with 28 individuals. These included 11 alpine samples (six from population Horntaler Joch and one each from the other populations), nine samples form northern Sweden (six from Latnjacorru and one each from Latnja, Latnjavaggi and Slåttatjåkka), and eight samples from Svalbard (five from the Todalen population and one each of the other three populations). The primers B11, C5, C19 and D2 produced no polymorphism at all; the remaining 17 primers (A9, A10, A12, A16, B5, B6, B12, B14, B15, B17, C6, C10, D1, D3, D13, D18, and D20) differentiated between alpine and arctic individuals, but showed no polymorphism within the main areas. To test whether there might be 
residual variation within the populations we selected five primers (B12, B15, C5, C6, and D18) for a more thorough survey using 93 individuals from 15 populations (Tab. 1). These primers had previously been tested on two Ranunculus alpestris individuals from each of three alpine populations, which resulted in the detection of six distinct genotypes (Bauert, unpublished data).

The 80 decamer primers (Operon A1-20, B1-20, C1-20, D1-20) were also screened for evidence of variation in $S$. cernua, with templates of one Scandinavian and one alpine individual. We then selected 18 primers that produced clear, polymorphic banding patterns and screened them with three individuals each of seven relict alpine populations from three different regions. Three groups of primers resulted: 1 . Banding patterns for primers C11, D1, D8 were identical for all 21 screened individuals from the three different relict regions; 2. Primers A7, A9, A17, A19, C15, C19, D8, D12, D16 showed identical banding patterns for all plants from the regions Valais and Engadine but a different pattern for the six plants from South Tyrol; 3. Primers A4, A11, A15, B15, C2, and D20 each produced three different patterns, one for each region. Subsequently, we selected primers A9 and C19 of group II and A4, A15, B15, and C2 of group III to investigate up to 23 individuals per population (in total 216 individuals; Tab. 1).

\section{Chromosome counts}

As we found a clear regional pattern in genetic variation among alpine populations of Saxifraga cernua, we used chromosome counts to verify this pattern. Only one chromosome count has been reported previously for alpine plants $(2 n=60$, Küpfer and Rais 1983). Our counts were carried out on root tips sampled in six of the alpine populations (one to three individuals per population). Root tips were pretreated for $0.5 \mathrm{~h}$ with colchicine $(0.05 \%)$, then fixed in ethanol/acetic acid $(3: 1)$, and stained and squashed in lacto-propionic orcein. The small size of the root tips and the large numbers of chromosomes made sampling, preparation and counting difficult, so that there may be minor errors in the reported chromosome numbers. No chromosome counts were carried out for the arctic populations, but large variation in chromosome numbers has been reported previously for arctic populations of $S$. cernua $(2 \mathrm{n}=24,36,44-52,55-57$, 60, 62, 64, 70, 72; Löve and Löve 1975; Webb and Gornall 1989).

\section{Statistical analysis}

We used the RAPDistance program (Armstrong J, Gibbs A, Peakall R, Weiller G, Australian National University, Canberra, Australia) to calculate four different similarity coefficients (Jaccard, Dice, Simple Matching, and Sneath and Sokal). The UPGMA trees (Sneath and Sokal 1973) produced using these various coefficients showed identical clusters and differed only in the lengths of the branches. We therefore present only the analyses using the Jaccard coefficient.

Simpson diversity index (Ds) adjusted for finite sample size (Peet 1974) was calculated for the various populations and regions:

$$
\text { Ds }=1-\Sigma\left\{\left[\mathrm{n}_{\mathrm{i}}\left(\mathrm{n}_{\mathrm{i}}-1\right)\right] /[\mathrm{N}(\mathrm{N}-1)]\right\}
$$

where $\mathrm{n}_{\mathrm{i}}=$ number of individuals with genotype $\mathrm{i}$ and $\mathrm{N}=$ total sample size 


\section{Results}

\section{Ranunculus pygmaeus}

We found no RAPD variation within populations of $R$. pygmaeus using either 21 primers on a limited sample of plants $(\mathrm{N}=28)$ or fewer primers on a larger sample $(\mathrm{N}=$ 93, Tab. 1). Indeed, we found only two RAPD phenotypes altogether - one for the plants from the Arctic (northern Sweden and Svalbard), and one for the six alpine populations (Fig. 1). These two phenotypes differed in 37 of the 120 scorable markers obtained from 21 primers.

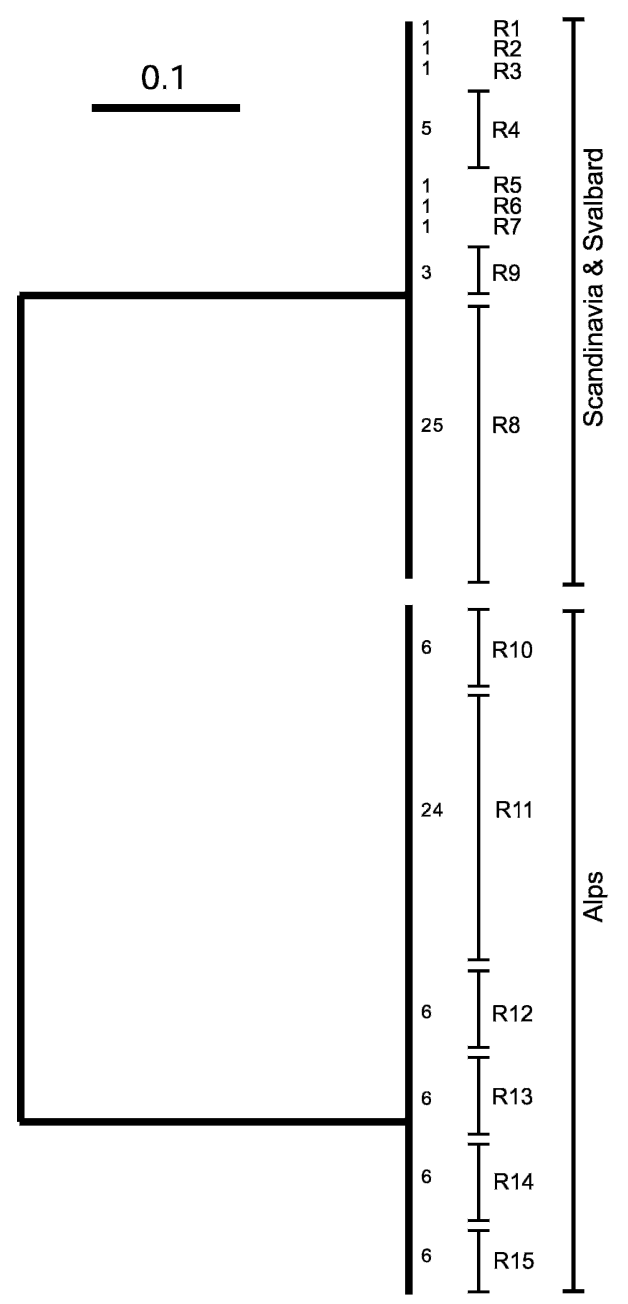

Fig. 1. Genetic structure of arctic and alpine populations of Ranunculus pygmaeus: UPGMA analysis based on Jaccard similarities between RAPD phenotypes. The tree is based on five primers producing 50 polymorphic markers. Numbers of investigated individuals are indicated. For population abbreviations (R1 - R15) see Table 1. 


\section{Saxifraga cernua}

In each of the arctic populations of $S$. cernua we found at least four RAPD phenotypes. Simpson diversity indices (adjusted for finite sample size of individual populations) range between 0.49 and 0.98 , indicating intermediate to high levels of genetic diversity (Tab. 1). The diversity indices calculated for all individuals of each region (Svalbard, Scandinavia and Ural) range between 0.71 to 0.96 (Tab. 1).

The size of the alpine populations ranged from six plants in the Sinabel population to several thousands on Piz Arina and Piz Alpetta (Tab. 1). However, even in the largest populations we found only one RAPD phenotype. Within the regions south-eastern Alps, central-eastern, and western Alps two phenotypes each could be detected. The diversity index for these regions ranges between 0.20 and 0.49 . However in Valais, Engadine, and South Tyrol the same phenotype was found in all populations.

There was a clear geographical structure in the genetic diversity of $S$. cernua. On one hand, arctic and alpine individuals are strongly separated in the UPGMA tree (Fig. 2). The Ural populations were distinct from both alpine and arctic populations, though slightly more similar to the arctic ones. On the other hand, there is a consistent regional structure within the main branches as well. All plants originating from either Svalbard or Scandinavia (northern Sweden) cluster together, with no "misplacement" of any individuals (Fig. 2). Likewise, the alpine populations from each of three regions cluster together, e.g. western, central-eastern and south-eastern Alps (Fig. 2). This regional structure was supported by chromosme counts: plants from the south-eastern Alps consistently had lower chromosome numbers $(2 n=42-48)$ than those from the western and central-eastern Alps $(2 \mathrm{n}=52-61$; Tab. 1, Fig. 2).

\section{Discussion}

\section{Origin of Ranunculus pygmaeus populations}

Despite the use of a large number of RAPD primers, we found only two genotypes of $R$. pygmaeus, one in the Alps and one in the Arctic (Scandinavia and Svalbard). The same primers were effective in demonstrating high genetic diversity in a different Ranunculus-species, $R$. alpestris, which is a diploid, self-incompatible outbreeder (Baltisberger and Müller 1981; Müller and Baltisberger 1984). We therefore suppose that the very limited genetic variation in R. pygmaeus is genuine and not simply a methodological problem resulting from the use of unsuitable primers. Our results confirm those of Schönswetter et al. (2006), who also found just two genotypes of $R$. pygmaeus based on chloroplast DNA, one in the Arctic (Scandinavia, British Columbia, Ural) and another in the Alps, Tatras and Taymyr. Furthermore, using the AFLP method, these authors found genetic variation to be much smaller in Scandinavia and in the Alps, each with one dominant AFLP phenotype, than in the other regions, which were genetically highly variable (Schönswetter et al. 2006). The lack of genetic diversity across large regions such as the Arctic and the Alps is not known of any other diploid, only sexually reproducing plant species. It is probably the result of inbreeding (see below) and of strong, repeated bottlenecks during early phases of colonization (Schönswetter et al. 2006). The data for R. pygmaeus therefore suggest that the two main regions (Arctic and Alps) have been colonized each from a single source represented by one genotype. These two origins were situated outside of the ice sheet 


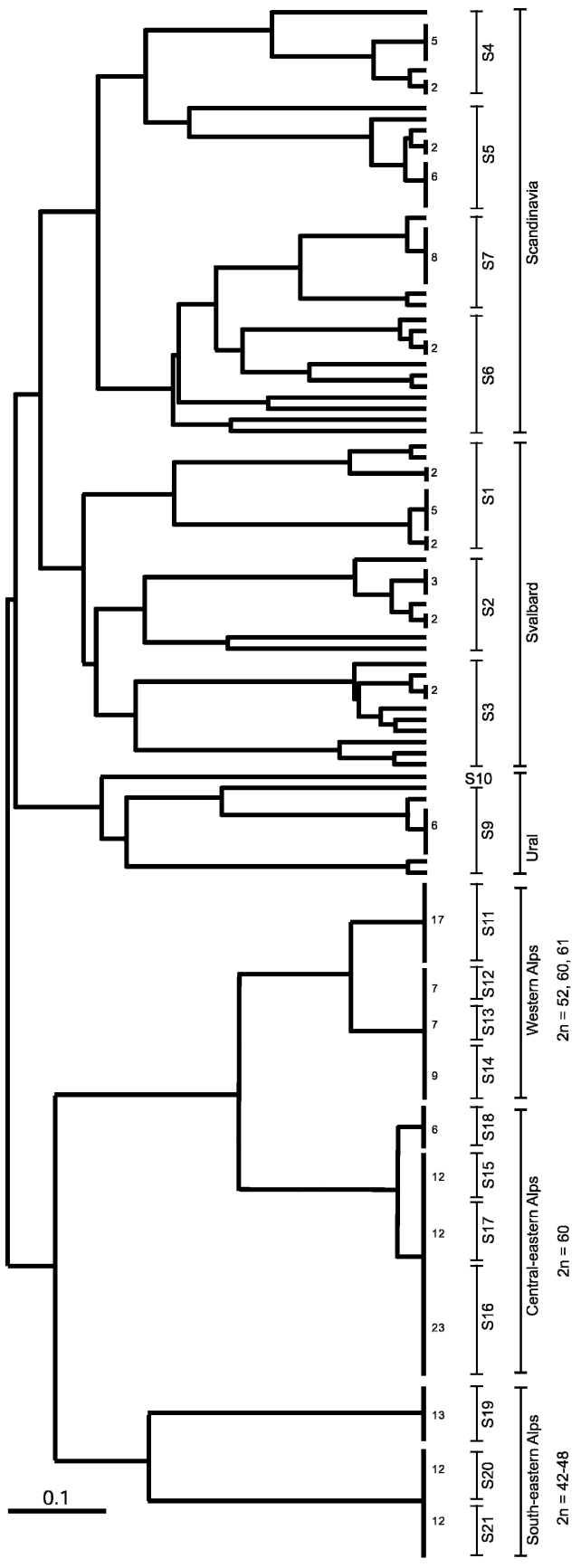

Fig. 2. Genetic structure of arctic and alpine populations of Saxifraga cernua: UPGMA analysis based on Jaccard similarities between RAPD phenotypes. The tree is based on six primers producing 180 polymorphic markers. Numbers of investigated individuals and chromosome numbers are indicated. For population abbreviations (S1-S21) see Table 1. 
during glaciation. As Schönswetter et al. (2006) pointed out, R. pygmaeus in the Alps probably immigrated from northern Siberia (most likely via the Tatra).

\section{Origin of alpine Saxifraga cernua populations}

In $S$. cernua, we found only six genotypes in 11 populations, with no variation within populations or even within sub-regions such as Valais and Engadine. This low level of genetic variation was probably the result of the extreme reduction and fragmentation of populations during successive glacial periods. Since the arctic and alpine populations are completely separated on the UPGMA tree, we favour the hypothesis of a refuge within the Alps over the alternative of a common source of recolonization from unglaciated regions lying between the alpine and arctic ice sheets. The fact that the south-eastern populations have lower chromosome numbers suggests that these populations might have a different history from other alpine populations.

We suggest that $S$. cernua probably reached the Alps before the Riss glaciation, which covered the Alps with a more extensive ice sheet than any other glaciation. Whereas any populations on the north side would have been eliminated at this time, the species may have survived in the less-glaciated south-eastern Alps, which also provided a refuge for many Tertiary relicts (Burga and Perret 1998; Stehlik 1999). After the Riss glaciation, $S$. cernua probably recolonized the Alps from the small, south-eastern refuges, but the genetic diversity of its populations was by then severely diminished, and may have declined further in subsequent glaciations.

\section{Origin of arctic Saxifraga cernua populations}

The arctic populations of $S$. cernua also showed a clear regional structure of RAPD variation, with the main branches of the UPGMA tree matching exactly the geographical distribution of the populations. Such a pattern might be expected if the founding genotypes evolved in situ, which would be consistent with the nunatak hypothesis. A problem with this interpretation, however, is the present high level of genetic diversity in the Svalbard populations. Our data from the Alps suggest that small relict populations of this species lose their genetic diversity, and it would therefore seem unlikely that their present diversity on Svalbard would have been maintained under the extreme conditions of a nunatak.

We cannot disprove the hypothesis that some Scandinavian populations did survive the glacial period in this way, but we think it more probable that at least some of the populations have immigrated from the eastern continental regions, which were less affected by the ice ages (Nordal and Jonsell 1998; Schönswetter et al. 2006). In this case, the close match between the genetic structure and the geographical distribution of populations in northern Scandinavia might be explained as the result of multiple longdistance dispersal events, with subsequent genetic differentiation by sexual reproduction and only limited regional dispersal.

In agreement with this interpretation, extensive genetic studies in nine plant species from Svalbard and surrounding continents have suggested that long-distance dispersal has not been limiting for long-term range shifts in the Arctic (Alsos et al. 2007). Drifting wood, debris of bank erosion along the Russian rivers or drifting sea ice may act as effective vectors for long-distance dispersal in the Arctic. Dispersal of diaspores is enhanced by the open arctic landscape, strong winds and extensive snow and ice cover. Migrating birds such as geese, which extensively graze in Svalbard during the summer, 
might also occasionally act as vectors of long-distance dispersal (Clausen et al. 2002). For example, we regularly observed vegetative propagules of Polygonum viviparum sprouting in geese dropings in Svalbard (Bauert pers. obs.). In the Alps, the highly structured topography, the absence of ice drift and the lack of large flocks of migrating birds probably result in a strongly limited range shift of plant species. Thus, the history of populations of the same species in the Alps and in the Arctic might have been completely different.

\section{Breeding system and genetic diversity}

The breeding system of species may influence how strongly their genetic diversity is affected by fragmentation and isolation. The two species studied here have contrasting breeding systems: Ranunculus pygmaeus is an inbreeding diploid which propagates only by seeds, while Saxifraga cernua is a clonal polyploid which propagates mainly by vegetative means.

The flowers of $R$. pygmaeus are commonly visited by small flies. However, viable seeds are produced even when flowers are covered with a bag (Tikhmenev 1984) or when a single plant is grown in isolation (Bauert pers. obs.), indicating that the species is self-fertile. We found most flowers in the Alps, Scandinavia and Svalbard to be inhabited by mites; these were usually covered with pollen. We assume that they facilitate self-pollination as they creep about within the flowers. Self-pollination may have further contributed to the absence of genetic variation presently observed in this species. Without selection, selfing leads to a $50 \%$ decrease in the level of heterozygosity at each generation (Mitton 1993), so that initial heterozygosity would be reduced to $0.1 \%$ after just 10 generations (Wright 1969). However, selfing cannot be the only reason for the absence of genetic variation in Scandinavian and alpine populations, since genetic diversity is much higher in other regions of the world (Schönswetter et al. 2006).

For $S$. cernua, both our study and previous ones have demonstrated intermediate to high levels of genetic diversity within arctic populations (Gabrielsen and Brochmann 1998). Although $S$. cernua mainly reproduces by vegetative means, viable seeds are produced occasionally (Molau and Prentice 1992; Brochmann and Hapnes 2001). Seed set has rarely been observed, but the fairly large, conspicuous flowers are visited by pollinators and produce seeds in good summers (Gabrielsen and Brochmann 1998). There appears to be sufficient outbreeding in arctic populations to maintain a moderate level of genetic diversity, suggesting that the role of sexual reproduction has been underestimated in the past.

Vegetative propagation in plants is usually regarded as an alternative to sexual reproduction under climatic conditions that are too harsh for reliable seed production. According to this view, it is a ,necessary evil' that carries a cost in terms of reduced genetic diversity of populations and hence a reduced ability to adapt to changing conditions. However, the high genetic diversity in arctic populations of S. cernua suggests a rather different significance for vegetative propagation - as a way of prolonging the life of a genotype and thus allowing more opportunities for seeds to be produced. Because an individual genotype of $S$. cernua is potentially very long-lived, it can ,afford to wait' for the rare occasions when cross pollination and seed set are possible. Thus, rather than being an alternative to sexual reproduction, a clonal growth form can be seen as a means of ensuring outbreeding under marginal climatic conditions. In contrast, $R$. pygmaeus does not reproduce vegetatively, and more 
frequent reproduction by seed is therefore essential. Inbreeding increases the reliability of seed production under difficult climatic conditions, but the consequence is the complete loss of heterozygosity and genetic uniformity within populations.

The question remains why there was no variation within alpine populations of $S$. cernua (consistent with results of Bauert et al. 1998), which implies that the long-lived clonal growth form has been insufficient to maintain genetic variation in isolated populations in the Alps. S. cernua also flowers and produces seeds in the Alps, but seed germination could never be observed despite different treatments (Bauert pers. obs.). The absence of sexual reproduction and therefore exclusively vegetative propagation (together with bottlenecks during colonization and postglacial recolonization events) might have led to genetically uniform regions in the Alps.

\section{Conclusions}

The lack of genetic diversity in alpine and Scandinvian populations of Ranunculus pygmaeus (in contrast to other parts of the world) clearly indicates postglacial colonization of each region from a single source. Conversely, the genetic structure of alpine Saxifraga cernua populations strongly suggests in-situ survival, whereas the origin of Scandinavian $S$. cernua populations remains ambiguous. On one hand, we found a clear regional genetic structure in the Arctic, similar to the Alps, suggesting in situ-survival. On the other hand, there is large within-population genetic diversity in Scandinavia but not in the Alps, suggesting more opportunities for genetic recombination in arctic populations. This might reflect either multiple postglacial colonization events through long-distance dispersal in the Arctic or the absence of sexual reproduction in the Alps, or both. Postglacial colonization and breeding systems have probably interacted in producing the different patterns of genetic diversity observed in $R$. pygmaeus and S. cernua.

\section{Zusammenfassung}

Ranunculus pygmaeus und Saxifraga cernua sind Pflanzenarten mit ähnlich disjunkter, arktisch-alpiner Verbreitung, aber mit unterschiedlicher Fortpflanzungsstrategie: Der diploide $R$. pygmaeus ist selbstbestäubend und pflanzt sich mittels Samen fort, $S$. cernua hingegen ist polyploid und vermehrt sich klonal durch vegetative Bulbillen. Mittels RAPDs untersuchten wir die genetische Variabilität innerhalb und zwischen Populationen beider Arten aus den Alpen, von Skandinavien, Spitzbergen und vom Ural. Trotz der Verwendung einer grossen Zahl von Primern fanden wir bei $R$. pygmaeus nur zwei Genotypen, einen in den Alpen und den anderen im arktischen Gebiet. Diese geringe genetische Diversität erklären wir mit postglazialer Einwanderung jeweils aus einer Ursprungspopulation und nachfolgender Selbstbestäubung. Bei S. cernua fanden wir in 11 Populationen der Alpen sechs Genotypen, jede Population nur mit einem einzigen Genotypen. Diese reduzierte genetische Variabilität in den Alpen geht wahrscheinlich auf die starke Verkleinerung und Fragmentierung der Populationen während der Eiszeiten zurück. Im Gegensatz dazu zeigten alle arktischen Populationen von S. cernua eine hohe genetische Variabilität, obwohl in dieser Art Samenproduktion nur selten beobachtet wurde. Wir schliessen, dass klonales Wachstum die Lebensspanne eines Genotyps stark verlängert und so unter erschwerten Bedingungen bei der sexuellen Fortpflanzung einen Vorteil darstellt. Wir vermuten, dass 
die hohe genetische Variabilität in den Populationen von Spitzbergen durch Einwanderung von Pflanzen nach den Eiszeiten und nicht durch Überdauerung auf Nunatakern in Spitzbergen zurückzuführen ist. Die regional unterschiedlichen Chromosomenzahlen und die starke regionale Gruppierung der einzelnen Genotypen von $S$. cernua in den Alpen interpretieren wir als Hinweis eines Überdauerns der maximalen Vereisung der letzten Eiszeiten im Randbereich der südlichen Alpen.

We thank the political authorities for collection permits for Tyrol, Carinthia and for the Communities Ramosch and Lavin (canton Grisons, Switzerland); Bruno Gallino, Felix Gugerli, Simonetta Peccenini, and Hansruedi Studer for accompaning and guiding during the field work; Ivan Sarapultsev for providing material from the Ural; and an anonymous referee for valuable comments on the manuscript. This work was funded by the Swiss National Science Foundation (no. 31-43182.95 to M. Baltisberger).

\section{References}

Alsos I. G., Eidesen P. B., Ehrich D., Skrede I., Westergaard K., Jacobsen G. H., Landvik J. Y., Taberlet P. and Brochmann C. 2007. Frequent long-distance plant colonization in the changing Arctic. Science 316: $1606-1609$.

Bachmann K. 1994. Molecular markers in plant ecology. New Phytol. 126: 403 - 418.

Baltisberger M. und Müller M. 1981. Vergleichende cytotaxonomische Untersuchungen an Ranunculus seguieri und der Artengruppe des R. alpestris (Ranunculaceae). Plant Syst. Evol. 138: $47-60$.

Bauert M. R. 1996. Genetic diversity and ecotypic differentiation on arctic and alpine populations of Polygonum viviparum. Arct. Alp. Res. 28: 190 - 195.

Bauert M. R., Kälin M., Baltisberger M. and Edwards P. J. 1998. No genetic variation detected within isolated relict populations of Saxifraga cernua in the Alps using RAPD markers. Mol. Ecol. 7: 1519 - 1527.

Berg R. 1963. Disjunksjoner I Norges fjellflora og de teorier som er fremsatt til forklaring av dem. Blyttia 21: 133 - 177.

Bettin O., Cornejo C., Edwards P. J. and Holderegger R. 2007. Phylogeography of the high alpine plant Senecio halleri (Asteraceae) in the European Alps: in situ glacial survival with postglacial stepwise dispersal into peripheral areas. Mol. Ecol. 16: 2517 - 2524.

Birks H. J. B. 1993. Is the hypothesis of survival on glacial nunataks necessary to explain the present-day distribution of Norwegian mountain plants? Phytocoenol. 23: 399 - 426.

Brochmann C., Gabrielsen T. M., Hagen A. and Tollefsrud M. M. 1996. Seed dispersal and molecular phylogeography: glacial survival, tabula rasa, or does it really matter? Det Norske Videnskaps-Akademi I. Matematisk-Naturvitenskapelig Klasse Ny Serie 18: 54 68.

Brochmann C., Gabrielsen T. M., Nordal I., Landvik J. Y. and Elven R. 2003. Glacial survival or tabula rasa? The history of North Atlantic biota revisited. Taxon 52: $417-450$.

Brochmann C. and Hapnes A. 2001. Reproductive strategies in some arctic Saxifraga (Saxifragaceae), with emphasis on the narrow endemic S. svalbardensis and its parental species. Bot. J. Linn. Soc. 137: 31 - 49.

Burga C. A. und Perret R. 1998. Vegetation und Klima der Schweiz seit dem jüngeren Eiszeitalter. Ott, Thun.

Clausen P., Nolet B. A., Fox A. D. and Klaassen M. 2002. Long-distance endozoochorous dispersal of submerged macrophyte seeds by migratory waterbirds in northern Europe: A critical review of possibilities and limitations. Acta Oecol. 23: $191-203$.

Dahl E. 1987. The nunatak theory reconsidered. Ecol. Bull. 38: 77 - 94.

Dahl E. 1997. The Phytogeography of Northern Europe. Cambridge University Press, Cambridge.

Doyle J. J. and Doyle J. L. 1991. Isolation of plant DNA from fresh tissue. Focus 12: 13-15. 
Ellstrand N. C. and Elam D. R. 1993. Population genetic consequences of small population size: Implications for plant conservation. Ann. Rev. Ecol. Syst. 24: 217 - 242.

Ellstrand N. C. and Roose M. L. 1987. Patterns of genotypic diversity in clonal plant species. Am. J. Bot. 74: 123 - 131.

Gabrielsen T. M., Bachmann K., Jakobsen K. S. and Brochmann C. 1997. Glacial survival does not matter: RAPD phylogeography of Nordic Saxifraga oppositifolia. Mol. Ecol. 6: 831 842.

Gabrielsen T. M. and Brochmann C. 1998. Sex after all: high levels of diversity detected in arctic Saxifraga cernua using RAPD markers. Mol. Ecol. 7: 1701 - 1708.

Gams H. 1933. Das Alter des alpinen Endemismus. Ber. Schweizer. Bot. Ges. 43: 467 - 483.

Hamrick J. L. and Godt M. J. W. 1989. Allozyme diversity in plant species. In: Brown A. H. D., Clegg T., Kahler A. L. and Weir B. S. (eds.). Plant Population Genetics, Breeding and Genetic Resources. Sinauer, Sunderland, MA, $43-63$.

Hamrick J. L. and Godt M. J. W. 1996. Effects of life history traits on genetic diversity in plant species. Phil. Trans. Royal Soc. London. B 351: 1291 - 1298.

Hantke R. 1983. Eiszeitalter, Band 3. Ott, Thun.

Holderegger R., Stehlik I. and Abbott R. J. 2002. Molecular analysis of pleistocene history of Saxifraga oppositifolia in the Alps. Mol. Ecol. 11: 1409 - 1418.

Jäckli H. 1965. Die Schweiz zur letzten Eiszeit. In: Atlas der Schweiz (ed. Schweizerischer Bundesrat). Eidgenössische Landestopographie, Wabern.

Kjolner S., Sastad S. M., Taberlet P. and Brochmann C. 2004. Amplified fragment length polymorphism versus random amplified polymorphic DNA markers: clonal diversity in Saxifraga cernua. Mol. Ecol. 13: 81 - 86.

Knapp E. E. and Connors P. G. 1999. Genetic consequence of a single founder population bottleneck in Trifolium amoenum (Fabaceae). Am. J. Bot. 86: 124-130.

Küpfer P. et Rais J.-R. 1983. Index des nombres chromosomiques des spermatophytes de la Suisse. I. Saxifragaceae. Bot. Helv. 93: $11-25$.

La Nicca R. 1945. Die "nordische" Saxifraga cernua L. in Graubünden und ihre Beziehung zu den eiszeitlichen Verhältnissen. Ber. Nat.forsch. Ges. Graubündens 80: 77 - 83 .

Lande R. and Shannon S. 1996. The role of genetic variation in adaptation and population persistence in a changing environment. Evolution 50: $434-437$.

Lewis P. O. and Crawford D. J. 1995. Pleistocene refugium endemics exhibit greater allozymic diversity than widespread congeners in the genus Polygonella (Polygonaceae). Am. J. Bot. 82: $141-149$.

Löve A. and Löve D. 1975. Cytotaxonomical Atlas of the Arctic Flora. Cramer, Vaduz.

Melchior H. 1934. Zur Verbreitung der Saxifraga cernua L. in den Alpen. Ber. Dtsch. Bot. Ges. 52: $221-230$.

Mitton J. B. 1993. Theory and data pertinent to the relationship between heterozygosity and fitness. In: Thornhill N. W. (ed.). The Natural History of Inbreeding and Outbreeding. University Press, Chicago, $17-41$.

Molau U. and Prentice H. C. 1992. Reproductive system and populations structure in three arctic Saxifraga species. J. Ecol. 80: 149 - 161.

Mosseler A. J., Egger K. N. and Innes D. J. 1993. Life history and the loss of genetic diversity in red pine. Am. J. Bot. 80, Vol. 6 (Abstracts): $81-82$.

Müller M. und Baltisberger M. 1984. Cytotaxonomische Untersuchungen in der Artengruppe des Ranunculus alpestris (Ranunculaceae). Plant Syst. Evol. 145: 269 - 289.

Nordal I. and Jonsell B. 1998. A phylogeographic analysis of Viola rupestris: Three post-glacial immigration routes into the Nordic area? Bot. J. Linn. Soc. 128: 105 - 122.

Ozenda P. 1988. Die Vegetation der Alpen im Europäischen Gebirgsraum. Fischer, Stuttgart.

Peet R. K. 1974. The measurement of species diversity. Ann. Rev. Ecol. Syst. 5: 285 - 307.

Schönswetter P., Stehlik I., Holderegger R. and Tribsch A. 2005. Molecular evidence for glacial refugia of mountain plants in the European Alps. Mol. Ecol. 14: 3547 - 3555. 
Schönswetter P., Popp M. and Brochmann C. 2006. Rare arctic-alpine plants of the European Alps have different histories: the snow bed species Minuartia biflora and Ranunculus pygmaeus. Mol. Ecol. 15: 709 - 720.

Sneath P. H. A. and Sokal R. R. 1973. Numerical Taxonomy. Freeman, San Francisco.

Stehlik I. 1999. Nunataks and peripheral refugia for alpine plants during quarternary glaciation in the middle part of the Alps. Bot. Helv. 110: 25 - 30 .

Stehlik I. 2003. Resistance or emigration? Response of alpine plants to the ice ages. Taxon 52: $499-510$.

Tikhmenev E. A. 1984. Pollination and self-pollination potential of entomophilic plants in arctic and mountain tundras of the northeastern USSR. Soviet J. Ecol. 15: $166-172$.

Tollefsrud M. M., Bachmann K., Jakobsen K. S. and Brochmann C. 1998. Glacial survival does not matter - II: RAPD phylogeography of Nordic Saxifraga cespitosa. Mol. Ecol. 7: 1217 1232.

Webb D. A. and Gornall R. J. 1989. A Manual of Saxifrages and their Cultivation. Timber Press, Portland, OR.

Williams J. G. K., Kubelik A. R., Livak K. J., Rafalski J. A. and Tingey S. V. 1990. DNA polymorphisms amplified by arbitrary primers are useful as genetic markers. Nucleic Ac. Res. 18: $6531-6535$.

Wright S. 1969. Evolution and the Genetics of Populations. University Press, Chicago. 